\begin{tabular}{|c|c|c|}
\hline (1) & $\begin{array}{c}\text { Türkiye Tarımsal Araştırmalar Dergisi } \\
\text { dergipark.org.tr/tutad }\end{array}$ & $\begin{array}{l}\text { Turk J Agric Res } \\
\text { 2019, 6(2): 237-241 } \\
\text { ○ TÜTAD } \\
\text { ISSN: 2148-2306 }\end{array}$ \\
\hline 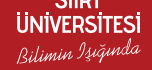 & Derleme / Review & $\begin{array}{l}\text { e-ISSN: } 2528-858 X \\
\text { doi: } 10.19159 / \text { tutad.460892 }\end{array}$ \\
\hline
\end{tabular}

\title{
Kinoa (Chenopodium quinoa Wild.)'nın Bazı Özellikleri ve Et Ürünlerinde Kullanımı
}

\author{
Osman KILINÇÇEKER*, Ali Mücahit KARAHAN \\ Adıyaman Üniversitesi, Teknik Bilimler Meslek Yüksekokulu, Gıda İşleme Bölümü, Adıyaman, TÜRKIYYE
}

\begin{tabular}{|c|c|}
\hline Geliş Tarihi/Received: 18.09 .2018 & Kabul Tarihi/Accepted: 11.04 .2019 \\
\hline \multicolumn{2}{|l|}{ ORCID ID (Yazar sirasma göre / by author order) } \\
\hline (1D) orcid.org/0000-0002-5222-1775 (10) 0000-0001-8779-4349 & \\
\hline
\end{tabular}

Öz: Bu çalışmada, kinoa (Chenopodium quinoa wild.)'nın gıda sanayii için önemli olan bazı özellikleri ve et ürünlerinde sağlayabileceği faydalar üzerinde durulmuştur. Özellikle kimyasal yapısı ele alınarak, et sektöründeki uygulamalarından örnekler verilmiştir. Kinoa, kazayağıgiller familyasından olan tek yıllık bir bitkidir. Genel olarak 0.5-1.5 m yüksekliğe ulaşabilir ve tohumunda tahıllara benzer bir yapı içerir. Kinoa tohumu yüksek miktarda kaliteli protein, yağ, mineral ve bazı vitaminler ile mükemmel bir besin bileşimine sahiptir. Ayrıca, glüten içermez ve bu nedenle glüten intoleransı olan kişiler tarafından rahatlıkla tüketilebilir. Kinoa tohumunun fonksiyonel özellikteki yüksek karbonhidrat ve protein içeriği, esansiyel yağ asitleri profili, antioksidan bileşikler ve yüksek demir içeriği nedeniyle et ürünleri üretiminde önemli faydalar sağlayabileceği düşünülmektedir. Ancak çalıșmalara bakıldığında, et ürünlerinde kinoa ile ilgili araştırmaların yetersiz olduğu gözlenmiştir. Dolayısı ile bu derlemede kinoanın sahip olduğu yapısal özelliklerden dolayı et ürünlerinin kalitesini geliştirmede katkısının olabileceği ve daha fazla deneysel çalışmaya ihtiyaç olduğu ortaya konulmuştur.

Anahtar Kelimeler: Kinoa, kimyasal özellikler, fonksiyonel özellikler, et ürünleri

\section{Some Properties of Quinoa (Chenopodium quinoa Wild.) and Its Usage in Meat Products}

\begin{abstract}
In this study, it is aimed to explain some of the properties of quinoa (Chenopodium quinoa Wild.) which are important for food industry and its benefits in meat products. Particularly, while mentioning the chemical structure, examples from the practices in the meat sector were given. Quinoa is an annual plant from the family of Chenopodiaceae. In general, it can reach a height of $0.5-1.5 \mathrm{~m}$ and contains a structure similar to grain in its seed. Quinoa seed contains high quality protein, fat, minerals and some vitamins and has an excellent nutritional composition. Additionally, it is gluten-free and therefore can be easily consumed by people with gluten intolerance. It is thought that quinoa can provide significant benefits in the production of meat products due to its high carbohydrate and protein content with functional properties, its profile of essential fatty acids, antioxidant compounds and high iron content. However, when the studies are examined, it is observed that the researches related to quinoa in meat products are insufficient. Therefore, in this review, it has been demonstrated that due to the structural features of quinoa, it may contribute to improve the quality of meat products and there is a need for more experimental studies.
\end{abstract}

Keywords: Quinoa, chemical properties, functional properties, meat products

\section{Giriș}

Değişen teknoloji ile birlikte insanların beslenme şekilleri de farklılaşmaktadır. Yoğun iş hayatı ve fiziki yorgunluk, kişileri fazla zaman kaybı olmadan hazırlanabilen gidalara yöneltmektedir. Dolayısı ile g1da üreticileri de bu tarz gidalara yönelmekte, farklı katkı maddelerini ve işleme 
tekniklerini kullanarak satışlarını arttırmaya çalışmaktadırlar (Kırpık ve Kılınççeker, 2018; Özer ve Seçen, 2018).

Bununla birlikte son yıllarda sağlıklı beslenme bilinci ile tüketiciler her ne kadar hazır yemeklere ilgi duysalar da, bunlar arasından sağlığa uygun ve kalorisi az olanları tercih etmekte; özellikle, hazırlaması kolay olan-ayakta tüketilen yiyeceklerde kullanılan bileşenleri, üretim metotlarını ve sağladıkları enerjiyi dikkate almaktadırlar (Shokry, 2016; Kırpık ve Kılınççeker, 2018).

Bunların yanı sıra gıda sektörü; çölyak, diyabet, kalp-damar rahatsızlığı veya sindirim bozukluğu gibi hastalıkları bulunan kişiler için farklı ürün üretimi yaparak insanlara alternatifler sunmaya çalışmaktadır. $\mathrm{Bu}$ tarz ürünlerin araştırılması, geliştirilmesi ve piyasaya sürülmesi ile uğraşan en önemli sektörlerden biri de et ürünleri ile uğraşan grup veya bu alan ile ilgili çalışan bilim adamlarıdır (Keskin ve Kaplan-Evlice, 2015; Demir ve Kılınç, 2016).

Et ürünleri sektöründe yapılan birçok çalışma ile bitkisel ve hayvansal kökenli bileşenler kullanılarak, tüketici için avantajları olan, çok sayıda alternatif ürünler ortaya çıkarılmıștır. Bu uygulamalara; çeşitli koruyucuların kullanımı, kıvam artırıcılar, renklendiriciler, protein gibi besin değerini düzenleyiciler veya bunların birçoğunu yapısında bulundurabilen farklı tahil unlarının kullanımı örnek olarak verilebilir. Özellikle unların kullanımı ile ilgili çalışmalarda, yapılarındaki nişasta veya protein gibi bileşenlerin sağladığ 1 fonksiyonel özellikler sayesinde ürün kalitesinin arttırılabileceği ile ilgili çeşitli bilgiler mevcuttur (Weiss ve ark., 2010; Kurt ve Kilınççeker, 2012; Tabarestani ve Tehrani, 2014; Kılınççeker, 2015).

$\mathrm{Bu}$ konuda son zamanlarda adı sıkça duyulan unlardan birisi kinoa (Chenopodium quinoa Wild.) tohumu unudur. Kinoa; tahıl olmayan, ancak bazı bileşenler yönünden içerikleri tahıllara benzeyen, boyu 40-150 cm arası olan, kazayağıgiller familyasından, tek yıllık bir bitkidir. Yassı ve oval şekilde tohumlara sahiptir. Çoğunlukla açık sarı renkte olan tohumlar, pembeden siyaha kadar değișen tonlara sahip olabilmektedirler (Karyotis ve ark., 2003).

Anavatanı Güney Amerika olan kinoanın M.Ö. 3000'li y1llara dayanan tarımı Avrupa'da da son zamanlarda yaygınlaşarak artmakta ve bu bitki ile ilgili araştırmalar yaygınlaşmaktadır. Türkiye'de ise yeni yeni tanınmaya ve yaygınlaşmaya başlayan kinoanın ithalatı yapılırken, tarımı ile ilgili çalışmalar da başlamıştır (Jacobsen, 2003; Kırpık ve Kilınççeker, 2018).
Yapılan bazı çalışmalarda, bu bitkinin tohumunun bileşimindeki maddelerden dolayı insan beslenmesinde önemli avantajlar sağlayacağ ekonomik kazanç sağlamada daha etkili olabileceği vurgulanmaktadır (Valencia-Chamorro, 2010; Repo-Carrasco ve Serna, 2011; Yildız ve ark., 2014).

Ancak literatüre bakıldığında özellikle Türkiye'de et ürünlerinde kinoanın kullanımı ile ilgili çalışmaların oldukça yetersiz olduğu anlaşılmıştır. $\mathrm{Bu}$ nedenlerden dolayı kinoanın bileşimine değinmenin ve et ürünlerindeki bazı uygulamalarına örnekler vererek sağlayabileceği faydaları üreticilerin göz önünde bulundurmalarını sağlamanın önemli olduğu düşünülmüştür. Bu derlemede kinoanın hem gida hazırlamada önemli bazı özellikleri hem de et ürünlerindeki bazı uygulamaları ortaya konularak, bu tohumu sektör için bitkisel bir alternatif olarak üreticiye sunmak hedeflenmiştir.

\section{Kinoanın Kimyasal Özellikleri}

Kinoa ve bazı tahıl tohumlarının önemli içerikleri ile ilgili ortalama değerler Tablo 1'de verilmiştir. Tablodan da anlaşılacağı üzere; bu bitkinin yüksek oranda protein, ya $\breve{g}$, karbonhidrat, mineral madde ve diyet özellikte lif içerdiği görülmektedir (Ahamed ve ark., 1998; Vilehe ve ark., 2003).

Tablo 1. Kinoa ve bazı tahılların kimyasal bileşen oranları (Repo-Carrasco ve ark., 2003)

\begin{tabular}{lcccc}
\hline Bileşenler (\%) & Kinoa & Buğday & Misır & Pirinç \\
\hline Protein & 14.4 & 10.5 & 11.1 & 9.1 \\
Yağ & 6.0 & 2.6 & 4.9 & 2.2 \\
Karbonhidrat & 72.6 & 78.6 & 80.2 & 71.2 \\
Ham lif & 4.0 & 2.5 & 2.1 & 10.2 \\
Kül & 2.9 & 1.8 & 1.7 & 7.2 \\
\hline
\end{tabular}

Tahıllarda en önemli ve yüksek oranda bulunan karbonhidratlardan bir tanesi nişastadır. Kinoanın yapısında \% 58.1-64.2 arasında nişasta bulunur. Buğday nişastasına göre daha yüksek su bağlama kapasitesine ve daha yüksek jelatinizasyon sıcaklığına sahiptir. Ayrıca donma ve çözünme gibi durumlarda daha stabil bir yapıya sahip olduğu belirtilmekte, bu özelliğinden dolayı modifiye nişastaların yerine bir alternatif olabileceği vurgulanmaktadır (Repo-Carrosco ve ark., 2003).

Ortalama protein miktarı kinoada yaklaşık olarak \% 15'tir. Bu miktar buğday ve diğer tahıllardan daha yüksek bir oran olup, su bağlama yeteneği olan çözünebilir protein oranı da buğday ve mısırdan oldukça yüksektir. Tohum yapısındaki proteinler bütün esansiyel amino asitleri içermekte olup, özellikle bitkisel yapılarda az bulunan lisin (\% 5.1-6.4) ve methionin (\% 0.4-1) bakımından 
zengindir (Chauhan ve ark., 1992; Ahamed ve ark., 1998).

Ayrıca soya ve buğdaydan daha fazla histidin amino asidi içermektedir. Yapısında glüten içermediğinden dolayı çölyak hastaları için önemli bir kaynaktır. Bu nedenle eklendiği gıdalarda protein kalitesini arttırmada önemli olabileceği vurgulanmaktadır (Enriquez ve ark., 2003).

Kinoa proteinin beslenme bakımından kalitesini vurgulamak için tavşanlar ile yapılan bir çalışmada, bu bitkinin proteininin sindirilebilirliğinin ve biyolojik değerinin diğer bazı tahıllara göre daha avantajlı olduğu vurgulanmış ve oransal değerler Tablo 2'de sunulmuştur (Ruales ve Nair, 1992).

Tablo 2. Kinoa proteininin beslenme bakımindan kalitesi (Ruales ve Nair, 1992)

\begin{tabular}{lccc}
\hline $\begin{array}{l}\text { Protein } \\
\text { kaynağ1 }\end{array}$ & Sindirilebilirlik & $\begin{array}{c}\text { Biyolojik } \\
\text { değer }\end{array}$ & $\begin{array}{c}\text { Net } \\
\text { protein } \\
\text { kullanımı }\end{array}$ \\
\hline Ham kinoa & 91.7 & 82.6 & 75.7 \\
Y1kanmış & 91.6 & 80.8 & 74.0 \\
kinoa & 87.6 & 58.1 & 50.9 \\
Misır & 89.6 & 59.0 & 52.9 \\
Buğday & 77.0 & 77.7 & 59.0 \\
Çavdar & 90.7 & 62.0 & 56.2 \\
Soya & & & \\
\hline
\end{tabular}

Birçok tahıla göre daha yüksek oranda (\% 4.58.75) yağ içeren kinoa, oleik (\% 24) ve linoleik (\% 52) asitler bakımından da zengindir. Özellikle elzem bir yağ asidi olan linoleik asit bakımından zengin olması, değerini arttırmaktadır. Çoklu doymamış yağ asitlerinin doymuş yağ asitlerine oranının soya, mısır ve zeytinyağı gibi yağlardan daha yüksek olduğu belirtilmektedir (Keskin ve Kaplan-Evlice, 2015). Bununla birlikte kinoa özellikle $\mathrm{E}$ ve $\mathrm{B}$ grubu vitaminler bakımından önemli bir kaynaktır. Yapılan çalışmalarda, kinoadaki $\gamma$-tokoferol miktarının 797 ppm, $\alpha$-tokoferol oranının ise $721 \mathrm{ppm}$ olduğu vurgulanmıştır. Özellikle $\gamma$-tokoferolün güçlü antioksidan aktivitesi nedeni ile kinoanın raf ömrünün de uzun olduğu belirtilmiştir. Bununla birlikte kinoa yapısında bir miktar riboflavin, tiyamin, folik asit ve $\mathrm{C}$ vitamini de bulunmaktadır (Repo-Carrasco ve ark., 2003; Demir ve Kılınç, 2016).

Mineral madde olarak kinoa magnezyum $(\mathrm{Mg})$, kalsiyum $(\mathrm{Ca})$, fosfor $(\mathrm{P})$, potasyum $(\mathrm{K})$, demir $(\mathrm{Fe})$, bakır $(\mathrm{Cu})$, mangan $(\mathrm{Mn})$ ve çinko $(\mathrm{Zn})$ yönünden zengin iken, sodyum $(\mathrm{Na})$ bakımından fakirdir. Özellikle $70-874 \mathrm{mg} 100 \mathrm{~g}^{-1}$ aralığında olan Ca ve 845-1201 mg $100 \mathrm{~g}^{-1}$ aralığında olan $\mathrm{K}$ içeriği yönünden diğer tahıllara göre oldukça avantajlıdır (Johnson, 1990; Ahamed ve ark., 1998).
Bunlara ek olarak, faydalı grup olan bazı biyoaktif bileşenler de kinoada bulunur. Özellikle bazı polifenoller, saponinler, flavonoidler ve fenolik asitler bunlara örnektir (Doğan ve Karwe, 2003; Demir ve Kılınç, 2016). Bu bileşenlerin vücuda alındıklarında; kolesterol seviyesini düşürdükleri, kansere karşı etkili oldukları, bağışıklık sistemini güçlendirdikleri ve kalp-damar hastalıklarını azaltabildikleri belirtilmektedir (Guzman-Maldonado ve Paredes-Lopez, 1998).

Beslenmede olumlu özelliklerinin yanı sıra, kinoanın anti besinsel bazı bileşenleri de bulunmaktadır. Bunların başında saponinler ve fitik asit gelmektedir. Ayrıca tripsin inhibitörleri de mevcuttur. Ancak bu bileşenler; yıkama, kabuk soyma veya isıl işlem ile azalmakta ya da inaktif olmaktadırlar (Valencia-Chamorro, 2010).

Kinoanın bahsedilen bu kimyasal özelliklerinden dolayı; et ürünlerinde, hatta su ürünlerinde de kullanımının çeşitli faydalar sağlayabileceği anlaşılmaktadır. Özellikle yapıtekstür düzenlemesi, besin içeriğinde düzenleme veya raf ömrünü arttırma gibi kriterlerde istenen yönde değişimler sağlayabileceği düşünülmektedir.

\section{Kinoanın Et Ürünlerindeki Uygulamaları}

Et ürünleri, hem üretim aşamasında hem de depolama esnasında kaliteyi korumak için birçok katkı maddesine ihtiyaç duyar. Özellikle yoğurma ve pişirme gibi aşamalarda ortaya çıkabilen duyusal problemlerin yanı sıra, depolamada oluşan oksidatif ve proteolitik bozulmaları azaltmak için gerçekleştirilen birçok çalışma yapılmıştır. $\mathrm{Bu}$ çalışmalarda, destek amaçlı kullanılan pek çok yapı düzenleyici ve koruyucu materyal var iken; yeni eğilim, herhangi bir olumsuz etkisi olmayan, hatta mevcut kaliteyi geliştirmeye yarayan doğal malzemelerin kullanımıdır (Tarte, 2009; Kurt ve Kılınççeker, 2012). Yukarıda bahsedilen özelliklerinden dolayı kinoa bu amaçlar için kullanılabilecek önemli bir kaynak olup, uygulamaları ile ilgili bazı çalışmalar bu bölümde sunulmuştur.

Timgren ve ark. (2013) farklı bitkisel kaynaklardan elde edilen modifiye nişastalardan en yüksek emülsiyon kapasitesine sahip olanın kinoa nişastası olduğunu; Fernandez-Diez ve ark. (2016), kuru sosis üretiminde, bileşime haşlanmış kinoa katmanın, duyusal kaliteyi değiştirmeden yağ oranını azalttığını, protein oranını arttırdı̆̆ını rapor etmiştir. Ayrıca bu çalışmada araştırılan mikrobiyal sayıların değişiminin istatistiksel olarak önemsiz olduğu saptanmıştır. 
Shokry (2016), et köftelerine soya unu yerine $\% 5, \% 10$ ve $\% 15$ oranında eklediği kinoa ununun köfte kalitesine etkisini incelediği çalışmada, bu unun kontrol örneği ve soya unu ile hazırlananlara göre, pişmemiş ve pişmiş örneklerdeki kaliteyi arttırdığını belirlemiş; özellikle pişmiş örneklerde, pişme kalitesi ve duyusal nitelikler artarken, renk değerlerinden parlaklık ve sarılığın iyileştiğini gözlemiştir.

Bağdatlı (2018) yaptığı araştırmasında, sı̆̆ır etinden hazırladığ kattığı kinoa unu ile; köftenin renk değerleri, nem ve yağ içeriğinin etkilendiğini, protein oranının geliştirilebildiğini, duyusal özelliklerin ise olumlu yönde etkilendiğini belirlemiştir.

Kırpık ve Kılınççeker (2018) farklı oranlarda kinoa unu ve galeta unu karışımları ile hazırladıkları tavuk köftelerde, kinoa unu katmanın kızarmamış örneklerde parlaklık ve sarılık değerlerini arttırdığını, kızarmış köftelerde verim ve renk değerlerini iyileştirirken, kızartma esnasında meydana gelen nem kaybını ve yă̆ emilimini azalttığını saptamışlardır.

Özer ve Seçen (2018) tarafindan yapılan çalışmada, yine et köftelere $\% 3, \% 5, \% 7$ ve $\% 10$ düzeyinde eklenen kinoa ununun ham ve pişmiş köftelerdeki bazı kalite özelliklerine etkisi araştırılmıştır. Çalışma sonunda, kinoa unu katmanın pişme verimi ve çap azalması gibi özellikleri geliştirdiği, kül ve protein içeriğini arttırdığı belirlenmiştir. Aynı çalışmada, bu unu katmanın tekstür değerlerini etkilerken, $-18^{\circ} \mathrm{C}$ de depolanan ham ve pişmiş örneklerde tiobarbütirik asit reaktif madde sayıs (TBARS)'nda azalma sağladığı gözlemlenmiştir.

Pellegrini ve ark. (2018) pişmiş et köfte hazırlamada bileşime yağ ile farklı oranlarda değişecek şekilde öğütülmüş beyaz, kırmızı ve siyah kinoa katıldığında; genel olarak örneklerde nem ve kül içeriğinin arttığını, yağ içeriğinin ise azaldığını belirlemişlerdir. Aynı çalışmada, kinoa katılması ile bazı örneklerde oksidasyonun azaldığ1 saptanırken; örneklerde aerobik bakteri, enterobakter mikroorganizma, maya ve küf bulunmadığı, en kabul edilebilir örneğin \% 5 kırmızı kinoa ile hazırlanan grup olduğu vurgulanmıştır.

\section{Sonuçlar}

Sonuç olarak, kinoanın et ürünlerini hazırlamada alternatif bir bitkisel katk1 olabileceği anlaşılmaktadır. Özellikle sahip olduğu renk özelliği, içerdiği protein, nişasta, lif oranları ve diğer bileşenler ile bunların fonksiyonel özelliklerinden dolayı ürün kalitesine önemli katkılar sağlayabileceği düşünülmektedir. Ancak yapılan çalışmalara bakıldığında özellikle kırmızı ve beyaz et ürünlerinde kullanımı ile ilgili verilerin yetersiz olduğu ve daha fazla uygulamaya ihtiyaç duyulduğu anlaşılmıştır. $\mathrm{Bu}$ nedenle, bu derleme memleketimizde tarımı yaygınlaştırılmaya çalışılan bu bitkinin et sektörü için, ürün kalitesini artırmada, alternatif kaynak olabileceğini göstermek amacıyla yazılmıştır.

\section{Kaynaklar}

Ahamed, N.T., Singhal, R.S., Kulkarni, P.R., Pal, M., 1998. A lesser-known grain, Chenopodium quinoa: Review of the chemical composition of its edible parts. Food and Nutrition Bulletin, 19(1): 61-70.

Bağdatlı, A., 2018. The influence of quinoa (Chenopodium quinoa Willd.) flour on the physicochemical, textural and sensorial properties of beef meatball. Italian journal of Food Sciences, 30(2): 280-288

Chauhan, G.S., Eskin, N.A.M., Tkachuk, R., 1992. Nutrients and antinutrients in quinoa seed. Cereal Chemistry, 69(1): 85-88.

Demir, M.K., Kılınç, M., 2016. Kinoa: Besinsel ve antibesinsel özellikleri. Journal of Food and Health Sciences, 2(3): 104-111.

Doğan, H., Karwe, M.V., 2003. Physicochemical properties of quinoa extrudates. Food Science and Technology International, 9(2): 101-114.

Enriquez, N., Peltzer, M., Raimundi, A., Tosi, V., Pollio, M.L., 2003. Characterization of wheat and quinoa flour in relation to their bread making quality. The Journal of the Argentine Chemical Society, 91(4-6): 47-54.

Fernandez-Diez, A., Caro, I., Castro, A., Salva, BK., Ramos, D.D., Mateo, J., 2016. Partial fat replacement by boiled quinoa on the quality characteristics of a dry-cured sausage. Journal of Food Science, 81(8): 1891-1898.

Guzman-Maldonado, S.H., Paredes-Lopez, O., 1998. Functional products of plants indigenous to Latin America: Amaranth, quinoa, common beans and botanicals. In: M. Mazza (Ed.) Functional Foods: Biochemical and Processing Aspects. Lancaster: Technomic Publishing Company, pp. 293-328.

Jacobsen, S.E., 2003. The worldwide potential for quinoa (Chenopodium quinoa Willd.). Food Reviews International, 19(1-2): 167-177.

Johnson, D.L., 1990. New grains and pseudo Grains. J. Janick and E. Simon (Eds.), Advances in new crops, Timber Press, Portland, OR, pp. 122-127.

Karyotis, T., Iliadis, C., Noulas, C., Mitsibonas, T., 2003. Preliminary research on seed production and nutrient content for certain quinoa varieties in a saline-sodic soil. Journal Agronomy and Crop Science, 189(6): 402-408.

Keskin, Ş., Kaplan-Evlice, A., 2015. Fırın ürünlerinde kinoa kullanımı. Tarla Bitkileri Merkez Araştırma Enstitüsü Dergis, 24(2): 150-156. 
Kilınççeker, O., 2015. Some quality caharacteristics of fish meatballs manufactured with different vegetablebased flours. Glda, 4(2): 61-67.

Kırpık, M., Kılınççeker, O., 2018. Use of quinoa flour in chicken meatball production. I. International Gap Agriculture and Livestock Congress, 25-27 April, Şanlıurfa, Turkey, p. 56.

Kurt, Ş., K1lınççeker, O., 2012. The Effects of cereal and legume flours on the quality characteristics of beef patties. Kafkas Üniversitesi Veteriner Fakültesi Dergisi, 18(5): 725-730.

Özer, C.O., Seçen, S.M., 2018. Effects of quinoa flour on lipid and protein oxidation in raw and cooked beef burger during long term frozen storage. Food Science Technology Campinas, 38(1): 221-227.

Pellegrini, M., Lucas-Gonzalez, R., Sayas-Barbera, E., Fernandez-Lopez, J., Perez-Alvarez, J.A., ViudaMartos, M., 2018. Quinoa (Chenopodium quinoa Willd) paste as partial fat replacer in the development of reduced fat cooked meat product type pâté: Effect on quality and safety. CyTA-Journal of Food, 16(1): 1079-1088.

Repo-Carrasco, R., Espinoza C., Jacobsen S.E., 2003. Nutritional value and use of the Andean crops quinoa (Chenopodium quinoa) and kaniwa (Chenopodium pallidicaule). Food Reviews International, 19(1-2): 179-189.

Repo-Carrasco, R., Serna, L.A., 2011. Quinoa (Chenopodium quinoa, Willd.) as a source of dietary fiber and other functional components. Ciencia $e$ Technologia de Alimentos, 31(1): 225-230.

Ruales, J., Nair, B.M., 1992. Nutritional quality of the protein in quinoa (Chenopodium quinoa, Willd.) seeds. Plant Foods for Human Nutrition, 42 (1): 1-11.
Shokry, A.M., 2016. The usage of quinoa flour as a potential ingredient in production of meat burger with functional properties. Middle East Journal of Applied Sciences, 6(4): 1128-1137.

Tabarestani, H.S., Tehrani, M.M., 2014. Optimization of physicochemical properties of low-fat hamburger formulation using blend of soy flour, split-pea flour and wheat starch as part of fat replacer system. Journal of Food Processing and Preservation, 38(1): 278-288.

Tarte, R., 2009. Ingredients in Meat Products: Properties, Functionality and Applications, Springer Sciences + Business media, LLC, 233 Spring street, New York, 10013, USA.

Timgren, A., Rayner, M., Dejmek, P., Marku, D., Sjoo, M., 2013. Emulsion stabilizing capacity of intact starch granules modified by heat treatment or octenyl succinic anhydride. Food Science and Nutrition, 1(2): 157-171.

Valencia-Chamorro, S.A., 2010. Qinoa. Ency-clopedia of food sciences and nutrition. Amsterdam: Academic Press.

Vilehe, C., Gely, M., Santalla, E., 2003. Physical properties of quinoa seeds. Bio Systems Engineering, 86(1): 59-65.

Weiss, J., Gibis, M., Schuh, V., Salminer, H., 2010. Advances in ingredient and processing systems for meat and meat products. Meat Sciences, 86(1): 196213.

Yıldız, M., Tans1, S., Sezen, S.M., 2014. New plants with commercial potent. Turkish Journal of Agricultural and Natural Sciences, Special Issue, 1(1): 1036-1042. 